heliport, and within a radius of half a mile of it under the take-off and landing paths.

Provided the site is carefully chosen, that is, on the Thames and in an area where the activities are mainly industrial and commercial, the quieter types of turbine-driven helicopter, as well as existing piston-engined types, should be able to use it at moderate frequencies without causing a serious problem. Whether the same would apply to high-frequency or night operations remains to be seen. Furthermore, tests carried out in open country and over London suggest that interference with television and veryhigh-frequency broadcasting is unlikely to be serious.

A continued effort will be needed to clarify the effects of the noise of helicopters and means of abating it. Research into noise abatement at source is being carried out by Government establishments and manufacturers. Meanwhile, proposals for heliport development should be expedited on the basis that noise can and will be brought down to reasonable levels.

After a preliminary survey, nine sites near the River within reasonable range of the West End have been examined and the following locations are considered the most promising: Nine Elms; Cannon Street Station; St. Katherine Doeks.

No attempt has been made to assess precisely the cost, since this is a matter for the promoters. The capital cost is likely to run into several millions of pounds, although it may vary considerably between one site and another. A single heliport of 12 acres should be capable of handling traffic well into the 1970 's, but will not be able to handle all the traffic indefinitely if the helicopter becomes accepted as a means of mass travel. The question of a second heliport must be left for a decision until nearer the time when the requirement is seen to emerge.

\title{
THE RED DEER IN SWEDEN
}

$\mathrm{F}_{\mathrm{b}}$ ROM information furnished by Å. Sjöström, in a bulletin from the Royal School of Forestry in Stockholm, it appears that the red deer in Sweden is now reduced to some 150 animals confined to three relatively isolated localities in the southern province of Skanne*. The paper gives the results of a study conducted over an area of about 740 acres within the Sövdeborg locality, which extends to some 4,300 acres and contains a herd of 30 deer. The annual hunting licence allowed the shooting of 5 animals but might be extended to equal the annual increase, which is 8. The area studied contains some 376 acres of Norway spruce plantations and 179 acres of beech forest, to which the deer do a considerable amount of damage, said to be due to a deficiency of certain nutrient elements in their diet. A careful assessment is made of the damage, which is caused mainly to trees from 15 to 45 years old, and leads to the

* Kungl. Skogshögskolans Skrifter. (Bulletin of the Royal School of Forestry, Stockholm.) Nr. 35: Rronhjortens Skadegorelse pó Grans kog: Esamensarbete vid Skogghogskolan i amnet Skogszoologi med Viltvård Otfört ar 1959. Av Ake Sjöström. Pp. 36. (Stockholm conclusion that the cost of producing one red deer is $4,000 \mathrm{kr}$. ( $\$ 280$ ). In a Danish deer-forest of some 7,200 acres with a head of 60-100 animals, Prof. Grøn has estimated that the cost of production of one animal is about $6,700 \mathrm{kr}$. (£465). Among the suggestions for dealing with these remnants of Sweden's original fauna are fencing of plantationsregarded as too expensive; change of tree-speciesthought to be a possible solution; use of chemical repellents - regarded as of doubtful and uncertain efficiency and too expensive; heavier shootinginapplicable in view of the already small number of animals; formation of red deer reserves and, finally, transfer to more suitable localities in natural spruce forests in west and central Sweden. One such transfer has already started. The interesting proposal is made that a charge of $10 \mathrm{kr}$. (14s.) per head on every roe deer, for which a shooting licence is required, should be levied. This would bring in about $300,000 \mathrm{kr}$. $(£ 20,800)$ a year, which would be used to purchase and maintain an area of suitable land where a new and vigorous stock of the Swedish red deer could be built up.

\section{O'NYONG-NYONG FEVER: AN EPIDEMIC OF VIRUS DISEASE IN EAST AFRICA}

$\mathrm{E}$ ARLY in 1959 an outbreak of unfamiliar disease appeared in human populations in the north-wast corner of Uganda, and spread across the northern half of the country in a south-easterly direction. The disease was usually characterized by headache, fever, adenitis and crippling joint pains, frequently followed on about the fourth day by an eruption of an itching rash, mainly on the trunk and arms. These symptoms usually persisted for 5-7 days and were generally followed by quick and complete recovery.

The clinical, and some of the epidemiological, aspects of the disease were investigated by Dr. $H$. Shore, the acting provincial medical officer in the Northern Province of Uganda, who reported that a dengue-like disease was affecting "vast numbers of people, old, young, men, women and children", and provisionally estimated from the rate of attack that at least 25-50 per cent of the population was at risk. That all ages were affected led him to suspect a causa. tive agent new to the region. This view is supported by the fact that the local African population have coined a new name for the disease in each successive language group in which it has appeared, one of the first of these being 'o'nyong-nyong'.

The epidemic advanced steadily on about a 100 . mile front for ten months, crossing the UgandaKenya border some 300 miles south-east of the original site of the disease in Uganda, in November, 1959. Between December 1959 and February 1960, the epidemic fanned out in the Kano Plains near Kisumu, Kenya. It is still active at discontinuous points east, south and west of Lake Victoria. From June, the epidemic has been under detailed study by members of the East African Virus Research Institute Staff, in close collaboration with mambers of the Uganda, Kenya and Tanganyika Medical Departments.

In a report*, prepared by J. D. Gillet, M. C. Williams, J. P. Woodall, P. S. Corbet and J. M. Ellice, it is shown that the isolation of o'nyong-nyong

- East Africa High Commission. East African Virus Research African Virus Research Institute, 1960.) 
virus allowed field epidemic studies and attempted transmission work to be followed virologically, and opened the way for quantitative investigations. These support the general epidemiological and vector findings that Anopheles species and, in particular, $A$. funestus are responsible for the transmission of a'nyong-nyong fever, but they do not exclude the possibility of transmission by $A$. gambiae. It is thought that this is the first time that a patchy alopecia has been used as an indicator in mice of arthropod-borne virus infection. An attempt has been made to messure three of the variable factors involved in order to gain an understanding of the epidemic. These are the mosquito infection-rate, the inapparent human infection-rate and the period of viræmia. Considereble work will be required before the success or failure of this attempt can be assegsed.

\title{
A WARNING SYSTEM FOR NUCLEAR ACCIDENTS
}

$\mathrm{R}$ ADIOACTIVITY, which was once the practical interest of no more than a few scientists and medical men, is now the daily concern of a great many people in most industrialized communities. Moreover, as events at Windscale demonstrated in Great Britain, radioactivity can be released accidentally in quantities sufficient to affect the life and livelihood of considerable numbers of the general population. With the increasing use of nuclear energy for peaceful purposes, nuclear installations will become more numerous, and, in the event of nuclear accident, radioactive material might be transmitted over wide areas and across national boundaries.

The decision of the Council of the Organization for European Economic Co-operation* to establish "a supervision and emergency warning system in cases of increase in environmental radioactivity" is therefore an important and encouraging step in international collaboration in the field of nuclear energy. The main purpose of the supervision and emergency warning system is to facilitate and improve health protection measures in the event of a substantial increase of radioactivity in any member country of the Organization for European Economic Co-operation by immediately notifying it to the responsible authorities in the other member countries. The transmission of information is to be governed by three criteria: (1) health protection in the event of a nuclear incident; (2) health aspects of an increase in environmental radioactivity of undefined origin; and (3) scientific interest of any case of abnormal increase in environmental radioactivity. As monitoring stations for measuring airborne radioactive material are already in existence in all member countries of the Organization the proposed system is to be based at first on air monitoring, although the importance of water and dietary contamination is recognized, and

* Report of the Steering Committee for Nuclear Fnergy and Counci Decision on the Establishment of a Supervision and Emergency Warning System in Cases of Increase in Environmental Radioactivity. Organization for European Economic Co-operation. Paris. July 7 ,
1961. extension of the system to these fields of monitoring is envisaged at a later stage.

The three levels of artificial total $\beta$-radioactivity in air, given as a basis for determining the categories of increase in radioactivity, are: (1) an 'emergency' level of the order of $1,000 \mu \mu \mathrm{c} . / \mathrm{m}^{3} ;$ (2) a 'pre-emergency' level of the order of $100 \mu \mu \mathrm{c} . / \mathrm{m}^{3}$; and (3) a level of 'scientific interest', set at ten times higher then the previous monthly average and exceeding the value of $5 \mu \mu c . / m .^{2}$. The levels are averages over one day, the 'emergency' level being determined in relation to possible nuclear incidents and regarded as valid for emergencies of short duration. Very approximately in terms of the Windscale reactor accident, the 'emergency' level corresponds to that observed within 50 miles (downwind) of Windscale itself, the 'pre-emergency' level to radioactivities observed at that time in Devon, and the level of 'scientifie interest' to observations made at some places on continental Europe. It should be noted that the warninglevels are those of artificial $\beta$-radioactivity, and that average levels of natural $\beta$-activity in the air in Great Britain are typically of the order of $100 \mu \mu \mathrm{c} . / \mathrm{m} .^{8}$.

An administrative organization is laid down, and reports are to be made to the European Nuclear Energy Agency as well as to the "designated authorities" in the member countries. After an initial period of two years operation, the Steering Committee for Nuclear Energy is to make a report to the Council of the Organization for European Economic Co-opera. tion on the way the system has worked.

Perhaps the most important aspect of the scheme is that it represents the beginning of collective action on a problem which transcends national boundaries, and that, as the Steering. Committee itself suggests, "when the supervision and warning system is set up, the possibilities of more extensive international collaboration should be considered". There would appear to be no insuperable difficulties to complete international collaboration on this aspect of the peaceful uses of nuclear energy.

F. W. SPIERS

\section{MOLECULAR DISARRAY IN A CRYSTAL LATTICE PRODUCED BY A FISSION FRAGMENT}

\author{
By DR. F. P. BOWDEN, C.B.E., F.R.S., and L. T. CHADDERTON \\ Physics and Chemistry of Solids, Cavendish Laboratory, Cambridge
}

T should be possible, if we choose an appropriate 1 crystal, to observe directly in the electron microscope the lattice disarray caused by the passage of a fission fragment, and an attempt has been made to do this. The first observations of erystal lattices and associated defects were made by Menter ${ }^{1}$ with phthalocyanine and its metal derivatives. These are polycyclic hydrocarbons with large flat molecules and the shape of the molecule influences the mode of crystallization. Platinum phthalocyanine, for ex- 